\title{
Identification of Vibrio campbellii isolated from diseased farm-shrimps from south India and establishment of its pathogenic potential in an Artemia model
}

Correspondence Shinji Yamasaki shinji@vet.osakafu-u.ac.jp Soumya Haldar shaldar@csmcri.org

Received 13 July 2010

Revised 30 August 2010

Accepted 13 September 2010

\section{Soumya Haldar, ${ }^{1} \dagger$ Shruti Chatterjee, ${ }^{1}$ Norihiko Sugimoto, ${ }^{1,2}$ Surajit Das, ${ }^{3}$ Nityananda Chowdhury, ${ }^{1}$ Atsushi Hinenoya, ${ }^{1}$ Masahiro Asakura ${ }^{1,2}$ and Shinji Yamasaki ${ }^{1}$}

${ }^{1}$ Graduate School of Life and Environmental Sciences, Osaka Prefecture University, Osaka, Japan

${ }^{2}$ Research and Development Centre, Fuso Pharmaceutical Industries Ltd, Osaka, Japan

${ }^{3} \mathrm{CAS}$ in Marine Biology, Annamalai University, Tamilnadu, India

\section{INTRODUCTION}

Halophilic vibrios such as Vibrio harveyi are ubiquitous in the marine environment and are implicated as the causes of several diseases in wild and cultured aquatic organisms. Due to the plasticity of Vibrio genomes, with frequent

†Present address: Discipline of Marine Biotechnology and Ecology, Central Salt and Marine Chemicals Research Institute (CSIR), G.B. Marg, Bhavnagar, Gujarat, India.

Abbreviations: ASW, artificial seawater; DOC, days of culture; DTAF, 5-(4,6-dichlorotriazin-2-yl)aminofluorescein; NJ, neighbour joining.

The GenBank/EMBL/DDBJ accession numbers for the sequence data for the experimental strains in this study are AB469289-AB469316 (16S rRNA), and AB469317-AB469324, AB469417-AB469436 $(p y r H)$. The accession numbers for the $V$. parahaemolyticus reference strain (Vp61) are AB561143 (16S rRNA) and AB561144 (pyrH).

Supplementary material is available with the online version of this paper. horizontal gene transfer events, species boundaries are very narrow in the marine environment (Fraser et al., 2007). Hence, the identification of $V$. harveyi and related species isolated from the marine environment is sometimes difficult. Luminous vibrios including $V$. harveyi have been implicated principally with disease outbreaks in shrimp larval culture facilities and grow-out ponds worldwide. Due to the high level of phylogenetic similarity among marine vibrios, bacteria associated with disease outbreaks have often been misidentified. For example, although strain LMG $19703^{\mathrm{T}}$ (or $A K 1^{\mathrm{T}}$ ) showed $99.4 \%$ sequence similarity in 16S rRNA with Vibrio mediterranei (ATCC $43341^{\mathrm{T}}$ ), Kushmaro et al. (2001) initially classified it as a new species, Vibrio shiloi, due to large differences in phenotypic properties. Later, Thompson et al. (2001), on the basis of genotypic features such as fluorescent amplified fragment length polymorphism and DNA-DNA hybridization, as 
well as phenotypic analyses, proposed that strain LMG $19703^{\mathrm{T}}$ should be considered as a subspecies of $V$. mediterranei. Similarly, two recently isolated crustacean pathogens were close to Vibrio campbellii, $V$. harveyi and $V$. rotiferianus, but DNA-DNA hybridization later proved them to be a new species, Vibrio owensii (Cano-Gómez et al., 2010). Misidentification of bacterial pathogens in fish/shrimp farm settings may create problems in selecting appropriate prophylactic measures. In recent years, sequencing and comparison of the $16 \mathrm{~S}$ rRNA gene has become an important tool for identification of bacterial species (Greenwood et al., 2005). However, V. harveyi and V. campbellii share more than $97 \%$ similarity in their $16 \mathrm{~S}$ rRNA gene sequences and show a $69 \%$ match in DNA-DNA hybridization (Gomez-Gil et al., 2004). Further, the wellstudied $V$. harveyi strain BB120 was recently proved to be $V$. campbellii by microarray-based comparative genomic hybridization (Lin et al., 2010). However, based on comparison of a series of housekeeping genes ( $p y r H, t o p A, f t s Z$ and $m r e B$ ) a few researchers have successfully identified and differentiated $V$. campbellii from $V$. harveyi (Thompson et al., 2007).

In addition to problems of accurate identification, a second challenge is to understand the virulence potential of marine vibrios, which is still difficult due to the lack of simple and reliable animal models. Nauplii of the brine shrimp Artemia have been used in many studies because this shrimp can be cultured easily in gnotobiotic conditions (Austin et al., 2005). Bacterial interaction or colonization with challenged organisms is a complex process. To study colonization potential, several techniques have been employed such as the use of cell lines (Olsson et al., 1992) and direct observation by scanning electron microscopy (Lavilla-Pitogo et al., 1990). These processes involve fixation and preparation of samples for microscopy, but do not permit in vivo observations of recently killed organisms or guarantee that the observed bacteria are those inoculated or of interest. Thus, the use of a pathogenic strain labelled with fluorescent dye was considered to be an appropriate method to study the in vivo colonization potential.

Vibriosis was reported during the months of October to December 2004 in three shrimp farms near Chennai, south India. In this study, we aimed to confirm the identification and to characterize bacterial strains isolated from the diseased shrimps and farm environments using molecular tools in addition to conventional culture techniques. We demonstrated the pathogenic potential and colonization abilities of $V$. campbellii strains using an Artemia model. Our studies indicate that $V$. campbellii may be a potential and emerging shrimp pathogen.

\section{METHODS}

Isolation place, sample collection and bacterial isolation. An incidence of disease was observed in the shrimp Penaeos monodon in three farms (here designated A, B, and C) with five, six and eight ponds, respectively, in north coastal Chennai, south India (see Supplementary Fig. S1, available with the online version of this paper). Average pond size was $0.5-1.0$ ha $\left(1 \mathrm{ha}=10000 \mathrm{~m}^{2}\right)$, with a stocking density of $8-12$ shrimps $\mathrm{m}^{-2}$ (semi-intensive culture). All three farms were located within a $9 \mathrm{~km}$ radius. Water supply to all ponds was from the Bay of Bengal through a common estuary. The water used was treated with $2 \%$ chlorine, followed by sedimentation for $24 \mathrm{~h}$ in a reservoir pond, and was finally supplied to the culture ponds through inlet canals. Two to four aerators (1 hp each) were used in each pond after 60 days of culture (DOC), depending upon the size of the pond. Salinity and $\mathrm{pH}$ were measured using a refractometer (Erma) and a $\mathrm{pH}$ pen (Eutech Instruments), respectively, twice daily starting from DOC60 (APHA, 1998), and the water temperature was measured once a day. All diseased and moribund shrimps were immediately stored in ice after collection and were analysed in the laboratory within 3-4 h. Samples were washed thoroughly with sterile distilled water. The hepatopancreas, muscles and gills of the diseased shrimps were dissected with sterile scissors and homogenized in physiological saline under aseptic conditions. Water samples were collected in duplicate at approximately $10 \mathrm{~cm}$ depth, using $100 \mathrm{ml}$ sterile plastic flasks. Sediments from the affected ponds were sampled with a bottom collector (Van Veen type) and two portions of the top $1 \mathrm{~cm}$ layer were transferred aseptically to UVsterilized plastic bags. Pond water and bottom soil samples were also included in this study to establish any possible epidemiological relationship with the experimental strains. Appropriate dilutions of homogenized samples from shrimp body parts (samples were collected from many shrimps) - hepatopancreas, muscle, gills, etc. - as well as pond water and bottom soil were plated on ZoBell's marine agar (Himedia) by spreading (Buck \& Cleverdon, 1960). Isolated bacteria from the body parts of shrimps were considered as shrimp disease isolates. A random selection of colonies was screened with an array of biochemical tests and stored in LB broth containing $3 \%$ sodium chloride and $25 \%$ glycerol at $-80{ }^{\circ} \mathrm{C}$.

Biochemical tests. Phenotypic characterization of all bacterial isolates was done following a scheme described elsewhere (Alsina \& Blanch, 1994; Holt et al., 1994). Details of the biochemical tests are described in the Supplementary Material.

Sequence analysis of 165 rRNA and pyrH genes. Genomic DNA was prepared according to the method of Ausubel et al. (2002). Partial sequencing of the 16S rRNA and uridylate kinase $(p y r H)$ genes was done for all 28 strains as described previously (Haldar et al., 2007; Thompson et al., 2007). The sequence of the pyrH gene from all experimental strains was compared with published sequence data in GenBank using BLAST (http://www.ncbi.nih.gov/BLAST). Alignment score and expect value ( $E$ value) were also evaluated. Highest scoring hit and lowest $E$ value were taken as possible matches (Ausubel et al., 2002).

For each experimental strain, the sequences for both 16S rRNA and pyrH genes were aligned and a phylogenetic tree was constructed with concatenated sequences by neighbour-joining (NJ) analysis using MEGA4 software (Kumar et al., 2008). Reference strains of $V$. campbellii (ATCC $25920^{\mathrm{T}}$ ) and $V$. harveyi (ATCC $14126^{\mathrm{T}}$ ) were used in the construction of the phylogenetic tree. Both 16S rRNA and pyrH sequences of the Vibrio core group members $V$. rotiferianus (CAIM573 and CAIM574) and V. parahaemolyticus (Vp61) were used as references and outgroup, respectively (Dorsch et al., 1992). The robustness of each topology was checked by 500 bootstrap replications.

The sequence data for the experimental strains have been submitted to the DDBJ/EMBL/GenBank databases under accession numbers AB469289-AB469316 (16S rRNA), and AB469317-AB469324, AB469417-AB469436 (pyrH). The accession numbers for the $V$. 
parahaemolyticus reference strain (Vp61) are AB561143 (16S rRNA) and AB561144 (pyrH).

PCR-based identification. A recently developed species-specific multiplex PCR targeting the haemolysin $(h l y)$ gene was also used to reconfirm the identification of V. campbellii and V. harveyi. Details of primer sequences and PCR conditions were as described by Haldar et al. (2010a).

Ribotyping. Genomic DNA of all the test strains was digested with the restriction enzyme BgII (Takara Bio) overnight at $37{ }^{\circ} \mathrm{C}$ and electrophoresed in $1 \%$ agarose gel with a Chef Mapper (Bio-Rad), using the Auto Algorithm program (separation limit of 1-25 kb). The DNA was then transferred to nylon membranes by Southern blotting. The membranes were hybridized under high-stringency conditions (Lin et al., 1993) with an $\left[\alpha_{-}^{32} \mathrm{P}\right] \mathrm{dCTP}\left(111 \mathrm{TBq}^{\mathrm{mmol}}{ }^{-1}\right.$; Perkin Elmer)-labelled $7.5 \mathrm{~kb}$ BamHI fragment of pKK3535 (Brosius et al., 1981; Faruque et al., 1994), and were then exposed to BAS film and analysed by FLA-3000 (Fuji Film).

Gnotobiotic Artemia culture. Artemia culture and challenge experiments were performed in autoclaved artificial seawater (ASW) prepared with seawater salt according to the instructions of the manufacturer (Matsuda). Artemia cysts were purchased from Tetra (Tokyo, Japan). All the experiments were performed with the same batch of Artemia nauplii. Bacteria-free nauplii were obtained by chlorination according to the procedure described by Defoirdt et al. (2005), with a slight modification (see the Supplementary Material for the decapsulation method). After hatching, 50 nauplii were randomly collected, ground and mixed with $100 \mu \mathrm{l}$ physiological saline in aseptic conditions, and bacterial counts were checked on LB agar. Healthy nauplii were transferred to ASW (500 nauplii in $100 \mathrm{ml}$ ) and maintained aseptically for 1 day.

Preparation of bacterial inocula. Several doses of bacteria were prepared according to the method of Gomez-Gil et al. (1998), with some modifications. Briefly, a single colony was inoculated into $3 \mathrm{ml}$ LB broth (Becton Dickinson) with $3 \%$ sodium chloride and the culture was incubated at $37{ }^{\circ} \mathrm{C}$ in an incubator shaker (Innova 4000, New Brunswick Scientific) at 180 r.p.m. for 15 h. One millilitre of freshly prepared bacterial culture was centrifuged at $9100 \mathrm{~g}$ for $5 \mathrm{~min}$ and bacterial inocula were prepared by adding an appropriate volume of ASW to the cell pellet to obtain an $\mathrm{OD}_{610}$ of 1.5 in a UV/vis spectrophotometer (Beckman Coulter).

Infection study. Thirty Artemia nauplii were transferred to a $15 \mathrm{ml}$ test tube with $6 \mathrm{ml}$ ASW $24 \mathrm{~h}$ after the chlorination treatment. The nauplii were kept for $6 \mathrm{~h}$ for acclimatization, and appropriate bacterial doses were added to obtain three concentrations, $10^{2}, 10^{5}$ and $10^{8}$ c.f.u. $\mathrm{ml}^{-1}$, in each tube for the challenge experiment. Coculture was done under sterile conditions in an incubator shaker (Innova 4300 ) at $26{ }^{\circ} \mathrm{C}$ with constant shaking (80 r.p.m.). Dead nauplii were collected and bacterial strains were isolated after $24 \mathrm{~h}$. Subsequently, 16S rRNA gene sequence was performed. After $48 \mathrm{~h}$, the numbers of live Artemia nauplii in each tube were counted and the mean percentage mortality $\left(\mathrm{M}_{\mathrm{obs}}\right)$ with standard deviation (SD) was calculated. Nauplii were not fed throughout the experimental period to keep the experimental set-up contamination free as described by Marques et al. (2005). Generally Artemia can survive in a healthy condition for up to $72 \mathrm{~h}$ without feeding (OrozcoMedina et al., 2002). All experiments were performed with three replicates per treatment.

Control experiments. $V$. harveyi strain BB120 (also known as BAA1116), recently identified as $V$. campbellii and reported to be pathogenic for Artemia nauplii, was used as a positive control (Bassler et al., 1997). A bacterium producing green colonies on thiosulphate-citrate-bile-sucrose agar (Nissui Pharmaceutical Co.) was isolated from an Artemia cyst. It was non-pathogenic and identified as Vibrio sp. by $16 \mathrm{~S}$ rRNA gene sequencing. This strain was used as a negative control. Another set of tubes containing only 30 Artemia nauplii in ASW without any bacterial inoculation was used as experimental control. Percentage mortality in this experimental control $\left(\mathrm{M}_{\text {control }}\right)$ was used for calculating corrected percentage mortality as described below. One hundred microlitres of water from the experimental control was plated on LB agar every day during the experimental period. Presence of a bacterial colony on either of these plates was considered as a failure of the experiment and the experiment was repeated.

Determination of the $\mathbf{L C}_{\mathbf{5 0}}$ (50\% lethal concentration). $\mathrm{LC}_{50}$ was determined using the probit method (Wardlaw, 1985) by plotting the $\log$ value of bacterial concentration ( $x$-axis) against the probit value of corrected percentage mortality ( $y$-axis). Corrected mortality was calculated by the following formula: Corrected mortality $(\%)=\left[\left(\mathrm{M}_{\mathrm{obs}}-\mathrm{M}_{\text {control }}\right) /\left(100-\mathrm{M}_{\text {control }}\right)\right] \times 100$.

There is no probit value for $0 \%$ or $100 \%$ corrected mortality. As a result, it was not possible to calculate $\mathrm{LC}_{50}$ values for strains which caused either $100 \%$ or $0 \%$ corrected mortality at any of the concentrations used.

Fluorescent labelling. The methodology described by SotoRodriguez et al. (2003a) for labelling bacteria with fluorescent dye was followed, with slight modification. A highly pathogenic (IPEY54) and a non-pathogenic (IPEY41) strain were labelled with the fluorescent dye 5-(4,6-dichlorotriazin-2-yl)aminofluorescein (DTAF) (see the Supplementary Material for details of the methodology).

Strains IPEY54 and IPEY41 were each inoculated at approximately $10^{5}$ c.f.u. $\mathrm{ml}^{-1}$ in a similar way as in the bacterial challenge study, and after $24 \mathrm{~h}$, accumulation of fluorescently labelled bacteria in the digestive tract was observed by fluorescence microscopy using a BP 470-490 $\mathrm{nm}$ excitation filter, DM $505 \mathrm{~nm}$ dichroic filter and BA 512$542 \mathrm{~nm}$ barrier filter with $100 \times$ magnification (Leica DFC350 FX, Leica Microsystems).

Colonization assay. The highly pathogenic strain IPEY54 and the non-pathogenic strain IPEY41 were selected to compare the colonization potentials. Hatching of Artemia nauplii in gnotobiotic conditions is described in the Supplementary Material. Bacterial doses were prepared as described above. A total of 375 nauplii were cultured in $75 \mathrm{ml} \mathrm{ASW}$ with approximately $10^{5}$ c.f.u. $\mathrm{ml}^{-1}$ of bacteria for $24 \mathrm{~h}$ at $26{ }^{\circ} \mathrm{C}$ with shaking at 80 r.p.m. to allow possible bacterial colonization of the Artemia nauplii. The bacterial dose was selected on the basis of a previous study (Soto-Rodriguez et al., 2006), where $10^{4}-10^{6}$ c.f.u. $\mathrm{ml}^{-1}$ of a luminous Vibrio were used to study the colonization potential against Litopenaeus vannamei larvae. Then 50 live Artemia were taken out and washed thoroughly with ASW without damaging any body parts. After this, all the nauplii were treated with $10 \mathrm{ml}$ ASW containing $50 \mu \mathrm{g}$ chloramphenicol ml $\mathrm{ml}^{-1}$, quickly transferred to fresh ASW without antibiotics and washed twice to remove all the bacteria loosely attached to the outer surface. This step was performed very rapidly to prevent engulfment of any antibiotics by the Artemia nauplii. Ten Artemia were crushed and plated with appropriate dilution on LB agar. The bacterial load in the surrounding water was also determined. Thirty Artemia were recultured in $6 \mathrm{ml}$ ASW for another $24 \mathrm{~h}$ to check bacterial accumulation and possible colonization inside the bodies of the nauplii. At the end of the assay, 10 crushed nauplii and $100 \mu \mathrm{l}$ surrounding water were plated again with appropriate dilution on LB agar. Colonization potentials were calculated by the following formula: Colonization potential $=\left[\right.$ (c.f.u. $\mathrm{ml}^{-1}$ per nauplius - c.f.u. $\mathrm{ml}^{-1}$ in surrounding water) after $\left.48 \mathrm{~h}\right] /\left[\right.$ (c.f.u. $\mathrm{ml}^{-1}$ per nauplius - c.f.u. $\mathrm{ml}^{-1}$ in surrounding water) after $24 \mathrm{~h}$ ]. 


\section{RESULTS}

\section{Epidemic information}

During 60 days of shrimp culture, the disease symptoms such as reduction of average daily growth and increase in food conversion ratio were first observed in the ponds of farm A, closest to the mouth of the estuary. In the following 2 weeks, similar symptoms were recorded in the other two farms (B and C). No viral disease such as white spot syndrome was reported from any of the ponds throughout the culture period. During culture the water temperature varied from 28 to $32{ }^{\circ} \mathrm{C}$ and the $\mathrm{pH}$ of the water was slightly alkaline (7.8-8.2).

\section{Biochemical characters}

Initially, 88 bacterial strains were biochemically tested (data not shown). All these strains were Gram-negative, oxidase-positive and negative for vibriostatic agent $\mathrm{O} / 129(10 \mu \mathrm{g})$; all showed no growth in $0 \%$ sodium chloride, and grew well in medium supplemented with 3-6\% sodium chloride. The results of the biochemical tests indicated that all the strains were halophilic Vibrio species. All the strains were negative for arginine dihydrolase reaction, and positive for indole production and gelatin production, establishing close identity with $V$. harveyirelated organisms. However, variable results were recorded for the majority of strains in the ornithine decarboxylase test, which is considered as the key test for differentiating $V$. campbellii from V. harveyi (Alsina \& Blanch, 1994).

\section{Identification by 165 rRNA and pyrH genes}

Among the 88 biochemically identified bacterial strains, 28 from different origins (Table 1) were randomly selected for further molecular characterization. When the $\mathrm{pyrH}$ gene sequences were compared with a non-redundant database at NCBI, 26 strains showed highest similarity (100\%) with published $V$. campbellii sequences and the remaining two with published $V$. harveyi sequences (data not shown). The lowest $E$ value was considered for all comparisons. Construction of a phylogenetic tree with concatenated sequences of $16 \mathrm{~S}$ rRNA (496 bp) and pyrH genes (467 bp) with MEGA4 software using $\mathrm{NJ}$ analysis revealed a similar identification pattern. The sequences of $V$. campbellii (ATCC $25920^{\mathrm{T}}$ ) and $V$. harveyi (ATCC $14126^{\mathrm{T}}$ ) were used as references. $V$. rotiferianus and $V$. parahaemolyticus formed separate clusters (Fig. 1). Similar phylogenetic trees were formed when constructed with minimum-evolution (ME), maximum-parsimony (MP) and UPGMA analysis using the same MEGA4 software (data not shown). The pyrH gene-based phylogenetic tree using NJ analysis also successfully differentiated $V$. campbellii groups from $V$. harveyi (Supplementary Fig. S2).

\section{PCR-based identification}

Species-specific multiplex PCR targeting the V. campbellii and $V$. harveyi hly gene also clearly identified 26 strains as
$V$. campbellii and the remaining two as $V$. harveyi (data not shown).

\section{Ribotyping}

Ribotyping with BglI restriction enzyme revealed three distinct clusters among the 28 strains. Two $V$. harveyi strains (IPEY37 and IPEY52) formed cluster I. Clusters II and III each contained 13 strains. Cluster I differed from clusters II and III by four and five DNA bands, respectively (Fig. 2). In this study, BglI-based ribotyping was able to discriminate $V$. campbellii from $V$. harveyi successfully, but the intra-specific discrimination efficiency of $V$. campbellii was not very high. The strains of cluster I were nonpathogenic (Table 1). When an attempt was made to relate ribotype clusters to the origin of the strains, it was found that both strains of cluster I had originated from pond water, whereas the majority of strains in clusters II and III originated from diseased shrimps. An interesting correlation between time of isolation and ribotype clusters was found. Both strains of cluster I were isolated during DOC60 and all strains of cluster II were isolated throughout the culture period (DOC60 to DOC135). Strains of cluster III were isolated from the samples during the initial (DOC60 to DOC90) and later (DOC135) stages of culture, but not during DOC105 and DOC120.

\section{Pathogenic potential}

The pathogenic potential varied among the strains. The pathogenicity of each strain against Artemia nauplii was determined on the basis of $\mathrm{LC}_{50}$. Strains having an $\mathrm{LC}_{50}$ of $<10^{3}$ c.f.u. $\mathrm{ml}^{-1}$ were considered as highly pathogenic, those with an $\mathrm{LC}_{50}$ of $10^{3}$ to $10^{7}$ c.f.u. $\mathrm{ml}^{-1}$ as moderately pathogenic, and those with an $\mathrm{LC}_{50}$ of $>10^{7}$ c.f.u. $\mathrm{ml}^{-1}$ as non-pathogenic. $\mathrm{LC}_{50}$ was not determined for 11 nonpathogenic strains, which showed $0 \%$ corrected mortality at some of the bacterial doses $\left(10^{2}, 10^{5}\right.$ and $10^{8}$ c.f.u. $\left.\mathrm{ml}^{-1}\right)$. Of the 28 strains, 8 were highly pathogenic, 3 were moderately pathogenic and 17 were non-pathogenic in the Artemia experimental model (Table 1). The positive control strain BB120 showed moderate pathogenicity as expected (Bassler et al., 1997). Negligible mortality was observed in the negative control (Vibrio sp.). In the bacteria-free control, $6 \%$ average mortality was observed, which was used to calculate corrected mortality. Detailed results of the challenge experiment are shown in Supplementary Table S1. Among five environmental strains (pond and estuarine water, bottom soil), four (IPEY37, IPEY52, IPEY63 and IPEY77) were non-pathogenic and only one (IPEY60) was moderately pathogenic to Artemia nauplii.

\section{Colonization assay}

To examine the colonization potential of highly pathogenic and non-pathogenic V. campbellii strains, V. campbellii was labelled with fluorescent dye and used for challenge in the 
Table 1. Strain details and results of molecular identification, ribotype and pathogenic potential against Artemia

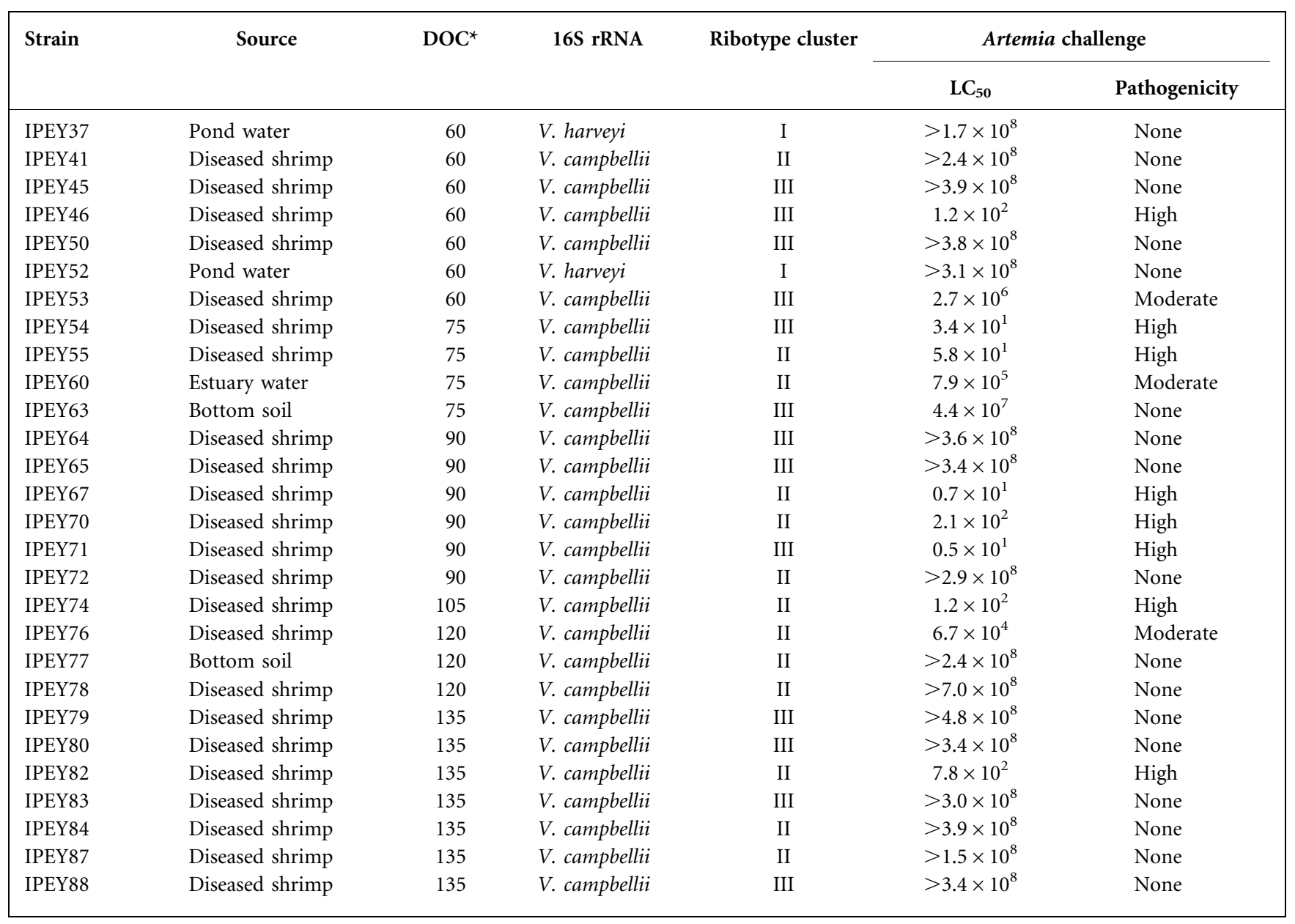

${ }^{\star}$ DOC, days of culture.

Artemia model. After fluorescent labelling (Fig. 3a), bacterial viability and growth (IPEY54) were not changed. Equal haemolytic zones were also observed for both fluorescently labelled and non-labelled strain IPEY54 (data not shown). These results indicated that the fluorescent dye did not have any adverse effect on the survival, growth and pathogenic expression of the experimental strains. When fluorescently labelled strain IPEY54 was observed by fluorescence microscopy, active motility was observed. Artemia challenged with fluorescently labelled pathogenic strain IPEY54 showed obvious patches of fluorescently labelled bacteria in the intestine of the nauplii (Fig. 3b), whereas no such clumps were observed in the case of fluorescently labelled non-pathogenic strain IPEY41 (Fig. 3c). In a control experiment, when Artemia was cultured with only fluorescent dye, the dye was observed in the whole of the digestive tract (Fig. 3d), due to its filterfeeding nature. After $24 \mathrm{~h}$ infection of Artemia nauplii with V. campbellii strains IPEY54 and IPEY41, the total bacterial counts were $13 \pm 0.3 \times 10^{6}$ c.f.u. $\mathrm{ml}^{-1}$ per nauplius and $82 \pm 7 \times 10^{5}$ c.f.u. $\mathrm{ml}^{-1}$ per nauplius, respectively. A sharp increase of 84-fold in bacterial counts for the highly pathogenic strain (IPEY54) and a slight decrease of 10-fold (0.1-fold increase) for the non-pathogenic strain (IPEY41) were found after $24 \mathrm{~h}$ when washed Artemia were kept in ASW without any bacterial inoculation (Table 2). This result indicates that the highly pathogenic strain IPEY54 can colonize and multiply inside the Artemia nauplii.

\section{DISCUSSION}

The Vibrio infection in the farmed shrimps was reported during the post-monsoon season, when the water temperature was increasing. Elevation in water temperature and constant alkaline $\mathrm{pH}$ may help the spread of Vibrio in the farm setting.

Identification of the causative agent is the first step towards understanding the nature of a disease in any setting. Hence, initially phenotype-based identification was carried out. However, phenotype-based identification of marine bacteria involves time-consuming techniques with low discriminating power (Alsina \& Blanch, 1994). Numerous studies have already been done to identify many Vibrio 


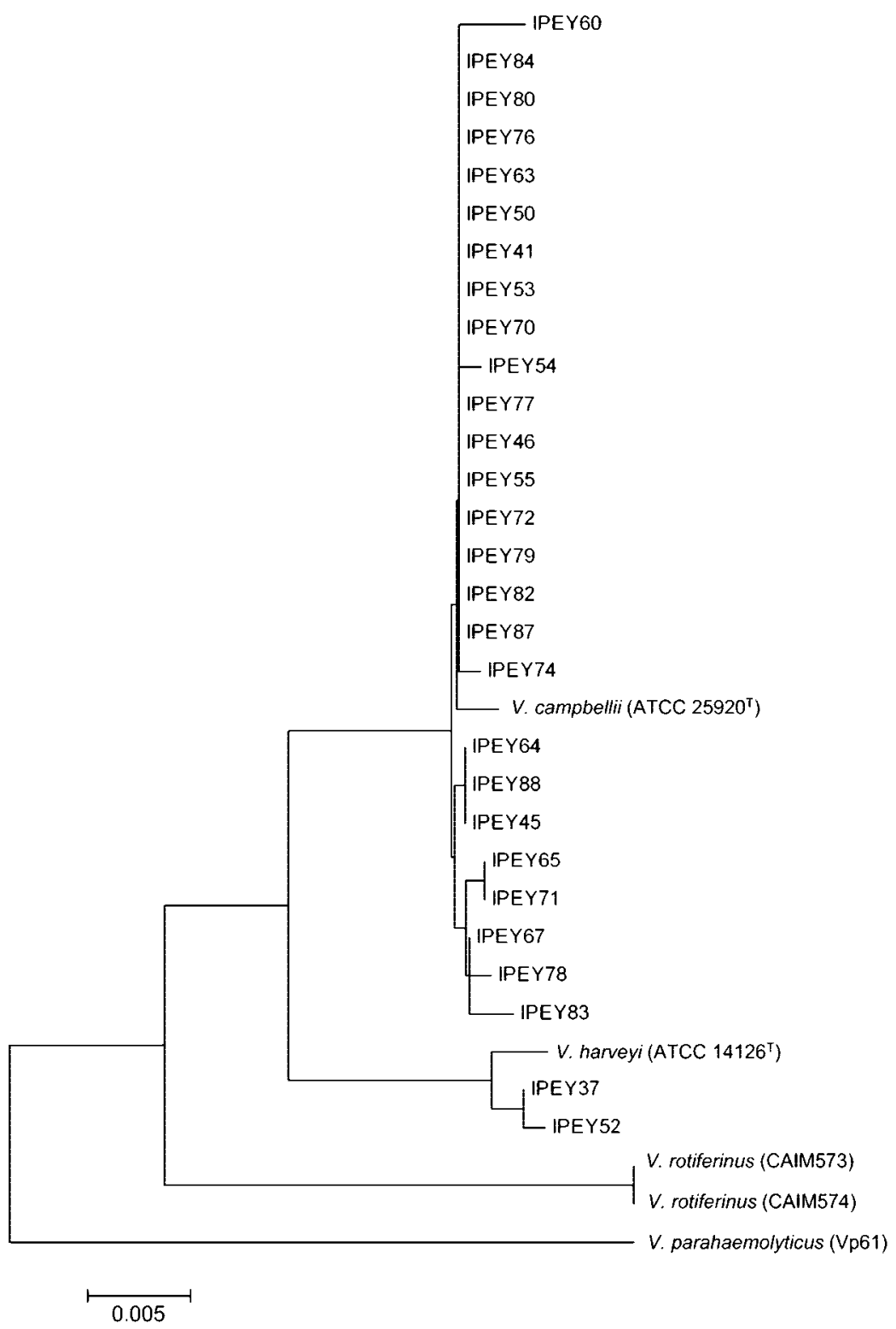

Fig. 1. Phylogenetic tree based on concatenated sequences of partial 16S rRNA pyrH genes using NJ analysis in the MEGA4 software. The V. campbellii type strain (ATCC $25920^{\top}$ ) clustered with a group of 26 experimental isolates, and the $V$. harveyi type strain (ATCC $14126^{\top}$ ) clustered with the other two experimental isolates. Sequences of the respective genes from two V. rotiferianus (CAIM573, CAIM574) strains and a V. parahaemolyticus (Vp61) strain were also included, and they were out-grouped.

species on the basis of biochemical tests, Biolog GN techniques, etc. However, these methods have failed to distinguish closely related vibrios like $V$. harveyi and $V$. campbellii (Thompson et al., 2004a, b; Fraser et al., 2007). In the present study, the biochemical tests gave preliminary indications that all 88 strains isolated from diseased shrimps and farm environments were presumptive Vibrio with considerable similarity to $V$. harveyi-related isolates, especially $V$. campbellii. Thus, a systematic attempt was made to correctly identify the disease-causing bacteria in the present study. To this end, 28 isolates of diverse origins within the shrimp farm ponds were randomly selected and characterized by different molecular tools. Thompson et al. $(2005,2007)$ analysed a series of housekeeping genes and concluded that there is no single gene which can clearly differentiate all species of vibrios. Further, it was reported that $V$. harveyi and V. campbellii have less than $97 \%$ pyrH gene sequence similarity and it is possible to differentiate a series of $V$. campbellii and $V$. harveyi species on the basis of this gene sequence (Thompson et al., 2007). The pyrH gene was therefore sequenced in this study to identify $V$. campbellii and $V$. harveyi correctly (Supplementary Table S1). A phylogenetic tree with concatenated sequences of the $16 \mathrm{~S}$ rRNA and pyrH genes using NJ analysis also supported the above identification (Fig. 1). To strengthen the precise identification, all identified strains were reconfirmed by a recently developed simple multiplex PCR method, which can easily and accurately identify $V$. campbellii and $V$. harveyi on the basis of the hly gene (Haldar et al., 2010a). Recently similar strategies were followed to successfully identify a number of disease-associated $V$. harveyi strains in a fish hatchery in Malta (Haldar et al., 2010b). 

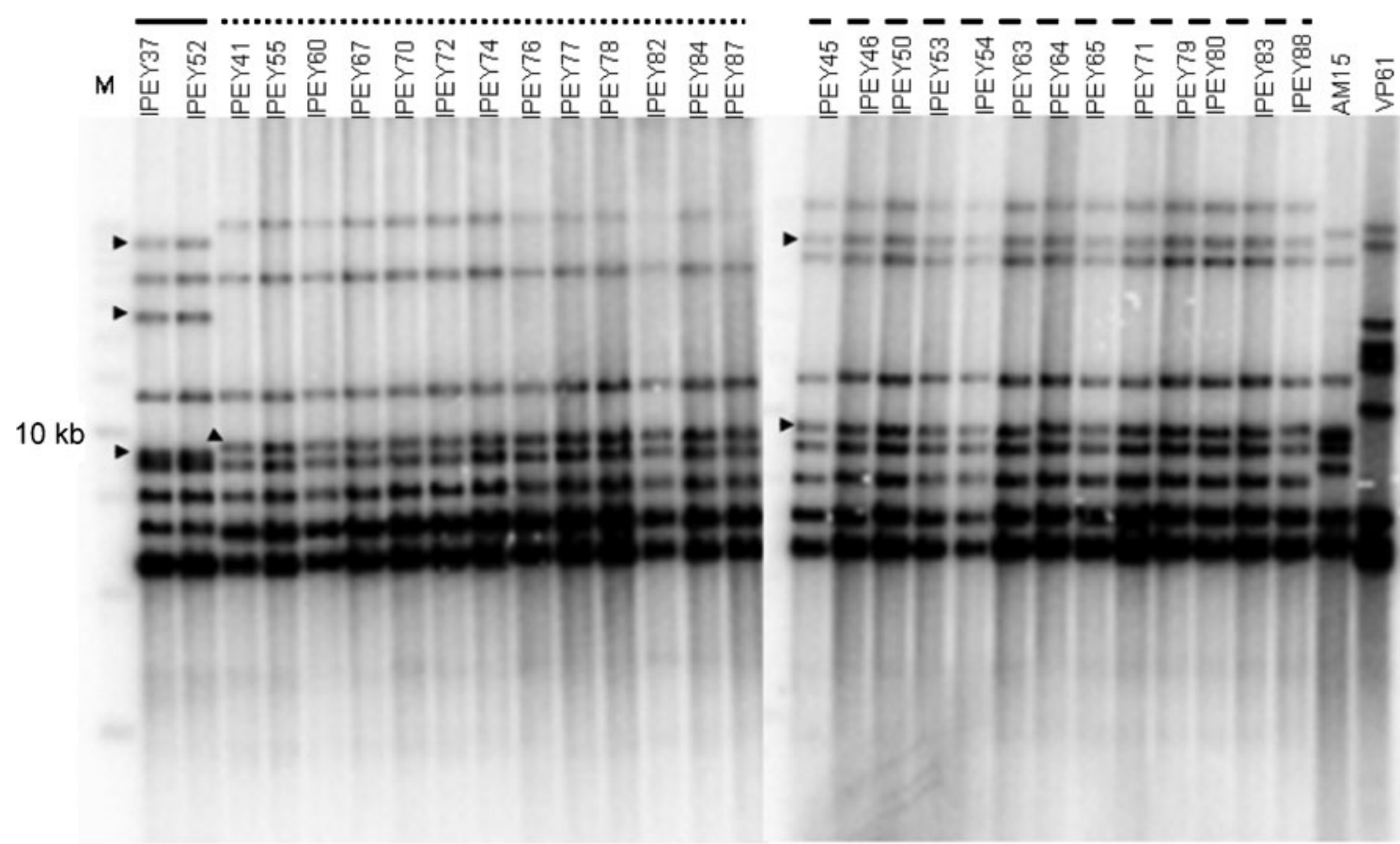

Fig. 2. Ribotype pattern of the test strains along with $V$. harveyi (AM15) and V. parahaemolyticus (Vp61) standard strains after digestion with $\mathrm{Bg} / \mathrm{l}$. Differences in DNA bands are indicated by arrowheads. The three clusters are marked by a solid line (cluster I), a dotted line (cluster II) and a dashed line (cluster III) above the figure.

After identification of disease-associated strains, the next major task was to evaluate the virulence potential of each strain. Artemia is an excellent model to study the mode of action of probiotics and pathogenic bacteria under gnotobiotic conditions (Marques et al., 2005). Austin et al. (2005) evaluated the pathogenic potential of several vibrios using rainbow trout and Artemia as test organisms. Their study revealed that some of the Vibrio species, such as $V$. brasiliensis, $V$. coralliilyticus, $V$. fortis, and $V$. neptunius, were highly pathogenic against Artemia nauplii, but $V$. campbellii was considered as a low- or nonpathogenic species. However, in the present investigation,
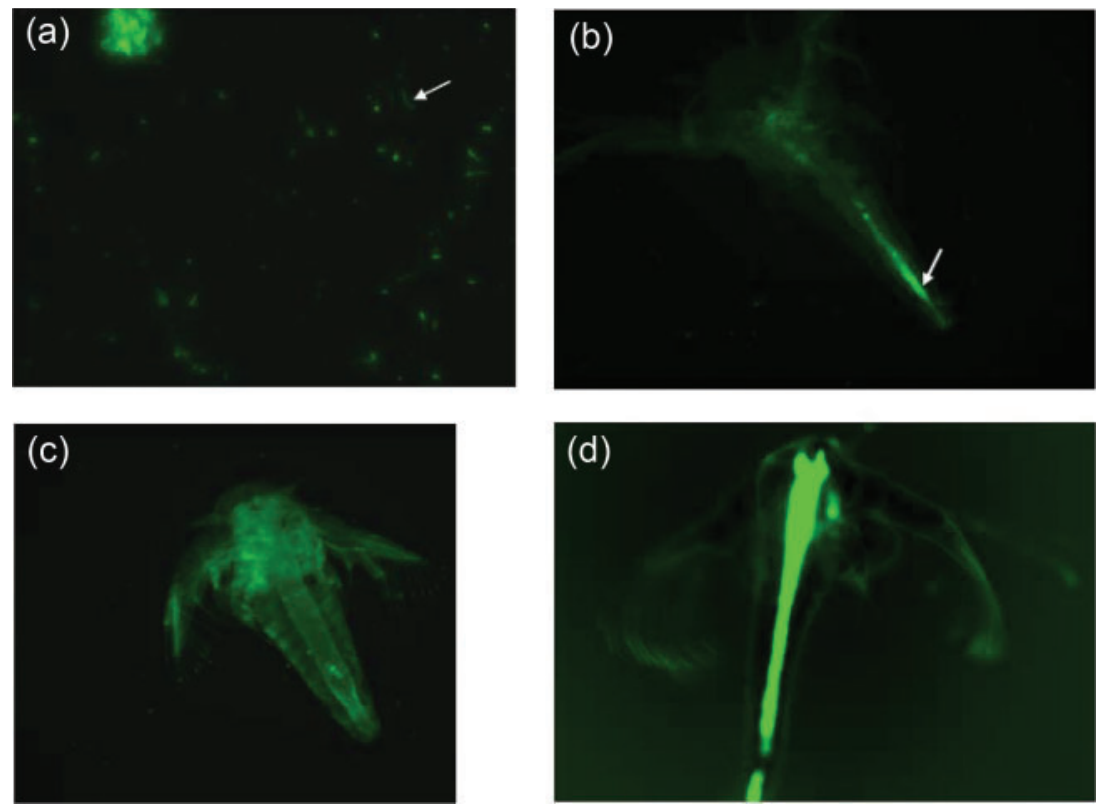

Fig. 3. Epifluorescent photomicrographs of fluorescently labelled highly pathogenic and non-pathogenic $V$. campbellii strains (strains IPEY54 and IPEY41, respectively). (a) Fresh mono-dispersed strain IPEY54 labelled with the fluorescent dye DTAF. Live fluorescently labelled bacteria are indicated by the arrow. (b) Clusters of fluorescently labelled bacteria in the midgut of an Artemia nauplius exposed to strain IPEY54 for $24 \mathrm{~h}$ at a density of $10^{5}$ c.f.u. $\mathrm{ml}^{-1}$. A patch of bacteria in the digestive tract is indicated by an arrow. (c) No fluorescent patch was observed in the midgut of an Artemia nauplius exposed to strain IPEY41 for $24 \mathrm{~h}$ at density of $10^{5}$ c.f.u. $\mathrm{ml}^{-1}$. (d) Artemia nauplius incubated with DTAF $(0.5 \mathrm{mg}$ $\mathrm{ml}^{-1}$ ) alone (control). All figures are magnified $\times 100$. 
Table 2. Colonization potentials of the highly pathogenic $V$. campbellii strain IPEY54 and the non-pathogenic strain IPEY41

\begin{tabular}{|c|c|c|c|c|c|c|c|}
\hline & \multicolumn{3}{|c|}{ Counts of IPEY54 (c.f.u. $\mathrm{ml}^{-1}$ ) } & \multicolumn{3}{|c|}{ Counts of IPEY41 (c.f.u. $\mathrm{ml}^{-1}$ ) } & \multirow{2}{*}{$\begin{array}{l}\text { C.f.u. } \mathrm{ml}^{-1} \text { in } \\
\text { control Artemia }\end{array}$} \\
\hline & Per nauplius & $\begin{array}{l}\text { In surrounding } \\
\text { water }\end{array}$ & $\begin{array}{c}\text { Fold } \\
\text { increase }^{\star}\end{array}$ & $\begin{array}{c}\text { Per } \\
\text { nauplius }\end{array}$ & $\begin{array}{l}\text { In surrounding } \\
\text { water }\end{array}$ & $\begin{array}{c}\text { Fold } \\
\text { increase }^{*}\end{array}$ & \\
\hline Initial load & 0 & 0 & & 0 & 0 & & 0 \\
\hline After $24 \mathrm{~h}$ & $13 \pm 0.3 \times 10^{6}$ & $1.2 \pm 0.1 \times 10^{2}$ & & $82 \pm 7 \times 10^{5}$ & $1.2 \pm 0.1 \times 10^{2}$ & & 0 \\
\hline After $48 \mathrm{~h}$ & $11 \pm 0.4 \times 10^{8}$ & $11 \pm 1.1 \times 10^{2}$ & 84 & $10 \pm 0.5 \times 10^{5}$ & $13 \pm 1.2 \times 10^{2}$ & 0.1 & 0 \\
\hline
\end{tabular}

${ }^{\star}$ Fold increase in counts per nauplius between 24 and $48 \mathrm{~h}$.

half of the V. campbellii strains isolated from diseased shrimps were moderately to highly pathogenic against Artemia nauplii. There are a few reports in which the pathogenic potentials of selected $V$. campbellii strains have been evaluated (Lavilla-Pitogo et al., 1990; Phuoc et al., 2008), but our study seems to be the first description of widespread damage caused by $V$. campbellii in a shrimp aquaculture setting. It would be interesting to challenge shrimp larvae with this set of strains, but a reproducible challenge protocol for penaeid larvae is not yet available (Soto-Rodriguez et al., 2003a).

It is well known that marine and estuarine environments provide a habitat where vibrios can be exposed to high levels of gene transfer by transduction (Jiang \& Paul, 1998), and consequently transfer of virulence factors may occur between marine bacteria (Hacker et al., 2003). The present study also indicated that some unknown factor(s) might have transformed half of the $V$. campbellii strains to be pathogenic against Artemia nauplii. Bacterial adherence to the epithelial cells is an important virulence determinant for many mucosal pathogens and is a prerequisite for the pathogenesis (Finlay \& Falkow, 1997). Using a paraffincarving technique Lavilla-Pitogo et al. (1990) observed that luminescent bacteria adhered to the oral region of $P$. monodon larvae. However, this technique is time consuming, and does not enable the pinpointing of the exact location of the bacteria. Moreover, when a particular strain is used, it does not guarantee its differentiation from the naturally occurring bacteria. Compared to the paraffincarving technique, use of a fluorescent stain has several advantages for specific marking of bacteria for pathological studies. It allows selective observation of bacteria inside and outside the host, ensuring that the inoculated bacteria alone are targeted. Using this technique, our challenge experiment showed that the highly pathogenic strain (IPEY54) colonized the gut after $24 \mathrm{~h}$. In the nonpathogenic strain (IPEY41), the number of fluorescently labelled bacteria was very low and no patches were observed in the gut. This result may indicate the association of the pathogenic strain with the mortality of Artemia nauplii. Another study suggested that Artemia franciscana nauplii have a maximum capacity for ingestion of bacterial cells ranging from $10^{2}$ to $10^{4}$ c.f.u. $\mathrm{ml}^{-1}$ per nauplius, independent of the bacterial density to which they are exposed but dependent on the bacterial strain employed (Soto-Rodriguez et al., 2003b). In the present study when the highly pathogenic (IEY54) and the nonpathogenic (IPEY41) strains were used for challenge at the concentration of $10^{5}$ c.f.u. $\mathrm{ml}^{-1}$ with Artemia nauplii, the bacterial load of IPEY54 increased from $10^{6}$ to $10^{8}$ c.f.u. $\mathrm{ml}^{-1}$ over a $24 \mathrm{~h}$ period; however, the mechanism of pathogenicity is not clear. We assume that $V$. campbellii must have had a high growth rate in the gut of Artemia, and cell invasiveness might be involved as previously reported in V. proteolyticus (Verschuere et al., 2000).

\section{Conclusions}

In this study, 88 strains were initially identified as $V$. harveyi-related bacteria by biochemical tests. In subsequent more detailed studies of 28 strains, the majority of the strains were found to be $V$. campbellii, establishing monospecific dominance during the period of shrimp culture. Given the absence of symptoms of viral infection such as white spot disease throughout the shrimp culture, and favourable environmental conditions, the disease seen in the shrimp farm ponds seems to have been caused by $V$. campbellii only. In addition the source water was the same for all the farms, which will have helped to spread the disease in a short time. We have demonstrated the pathogenic potential of $V$. campbellii in a crustacean model to support this view. This appears to be the first report regarding the isolation of large numbers of $V$. campbellii from diseased shrimp farms and demonstrating their pathogenicity in an Artemia experimental model. It will be worthwhile to study the mechanisms of pathogenicity to help develop prophylactic measures against this newly emerging Vibrio sp. to reduce its spread.

\section{ACKNOWLEDGEMENTS}

We sincerely thank Dr T. Ramamurthy, National Institute of Cholera and Enteric Diseases (ICMR), Kolkata, India, for critically reading the manuscript. We also thank Dr S. M. Faruque, International Centre for Diarrhoeal Disease Research, Bangladesh, for kindly providing us pKK3535. We also thank Dr M. Vijayakumaran, NIOT, and Mr T. Banerjee, CSMCRI, for their valuable comments. This study was 
performed in partial fulfilment of the requirements of a $\mathrm{PhD}$ thesis for S.H. from the Graduate School of Life and Environmental Sciences, Osaka Prefecture University, Osaka, Japan. The Ministry of Education, Culture, Sports, Science and Technology of Japan (MEXT) provided S. H. and N.C. with Monbusho Scholarships.

\section{REFERENCES}

Alsina, M. \& Blanch, A. R. (1994). A set of keys for biochemical identification of environmental Vibrio species. J Appl Bacteriol 76, 7985.

APHA (1998). US Standard Methods For Examination Of Water And Wastewater, 20th edn. Washington: American Public Health Association.

Austin, B., Austin, D., Southerland, R., Thompson, F. \& Swings, J. (2005). Pathogenicity of vibrios to rainbow trout (Oncothynchus mykiss, Walbaum) and Artemia nauplii. Environ Microbiol 7, 14881495.

Ausubel, F. M., Brent, R., Kingston, R. E., Moore, D. D., Seidman, J. G., Smith, J. A. \& Struhl, K. (2002). Short Protocols in Molecular Biology, 5th edn, pp. 2-11. New York: Wiley.

Bassler, B. L., Greenberg, E. P. \& Stevens, A. M. (1997). Crossspecies induction of luminescence in the quorum-sensing bacterium Vibrio harveyi. J Bacteriol 179, 4043-4045.

Brosius, J., Ullrich, A., Raker, M. A., Gray, A., Dull, T. J., Gutell, R. R. \& Noller, H. F. (1981). Construction and fine mapping of recombinent plasmids containing the rRNB ribosomal RNA operon of E. coli. Plasmid 6, 112-118.

Buck, J. D. \& Cleverdon, R. C. (1960). The spread plate as a method for the enumeration of marine bacteria. Limnol Oceanogr 5, 78-80.

Cano-Gómez, A., Goulden, E. F., Owens, L. \& Hoj, L. (2010). Vibrio owensii sp. nov. isolated from cultured crustaceans in Australia. FEMS Microbiol Lett 302, 175-181.

Defoirdt, T., Bossier, P., Sorgeloos, P. \& Verstraete, W. (2005). The impact of mutations in the quorum sensing systems of Aeromonas hydrophila, Vibrio anguillarum and Vibrio harveyi on their virulence towards gnotobiotically cultured Artemia franciscana. Environ Microbiol 7, 1239-1247.

Dorsch, M., Lane, D. \& Stackebrandt, E. (1992). Towards a phylogeny of the genus Vibrio based on $16 \mathrm{~S}$ rRNA sequences. Int J Syst Bacteriol 42, 58-63.

Faruque, S. M., Alim, A. R. M., Roy, S. K., Khan, F., Nair, G. B., Sack, R. B. \& Abert, M. J. (1994). Molecular analysis of rRNA and cholerae toxin genes carried by the new epidemic strains of toxigenic Vibrio cholerae synonym Bengal. J Clin Microbiol 32, 1050-1053.

Finlay, B. B. \& Falkow, S. (1997). Common themes in microbial pathogenicity revisited. Microbiol Mol Biol Rev 61, 136-169.

Fraser, C., Hanage, W. P. \& Spratt, B. G. (2007). Recombination and the nature of bacterial speciation. Science 315, 476-480.

Gomez-Gil, B., Maria, A., Vega, H., Alberto, F., Grobois, A. \& Roque, A. (1998). Bioencapsulation of two different Vibrio species in nauplii of brine shrimp (Artemia franciscans). Appl Environ Microbiol 64, 23182322.

Gomez-Gil, B., Soto-Rodríguez, S., Garcia-Gasca, A., Roque, A., Vazquez-Juarez, R., Thompson, F. L. \& Swings, J. (2004). Molecular identification of Vibrio harveyi-related isolates associated with diseased aquatic organisms. Microbiology 150, 1769-1777.

Greenwood, S. J., Keith, I. R., Despres, B. M. \& Cowthorn, R. J. (2005). Genetic characterization of the lobster pathogen Aerococcus viridans var. homari by $16 \mathrm{~S}$ rRNA gene sequence and RAPD. Dis Aquat Organ 63, 237-246.
Hacker, J., Hentschel, U. \& Dobrindt, D. (2003). Prokaryotic chromosome and disease. Science 301, 790-793.

Haldar, S., Chatterjee, S., Asakura, M., Vijayakumaran, M. \& Yamasaki, S. (2007). Isolation of Vibrio parahaemolyticus and Vibrio cholerae (non-O1 and O139) from moribund shrimp (Penaeus monodon) and experimental challenge study against post larvae and juveniles. Ann Microbiol 57, 55-60.

Haldar, S., Neogi, S. B., Kogure, K., Chatterjee, S., Chowdhury, N., Hinenoya, A., Asakura, M. \& Yamasaki, S. (2010a). Development of a haemolysin gene-based multiplex PCR for simultaneous detection of Vibrio campbellii, Vibrio harveyi and Vibrio parahaemolyticus. Lett Appl Microbiol 50, 146-152.

Haldar, S., Maharajan, A., Chatterjee, S., Hunter, S. A., Chowdhury, N., Hinenoya, A., Asakura, M. \& Yamasaki, S. (2010b). Identification of Vibrio harveyi as a causative bacterium for a tail rot disease of seabream Sparus aurata from research hatchery in Malta. Microbiol Res Feb 1 [Epub ahead of print].

Holt, J. G., Krieg, N. R., Sneath, P. H. A., Staley, T. \& Williams, S. T. (1994). Bergey's Manual of Determinative Bacteriology, 9th edn. Baltimore, MD: Williams and Wilkins.

Jiang, S. C. \& Paul, J. H. (1998). Gene transfer by transduction in the marine environment. Appl Environ Microbiol 64, 2780-2787.

Kumar, S., Dudley, J., Nei, M. \& Tamura, K. (2008). MEGA: a biologistcentric software for evolutionary analysis of DNA and protein sequences. Brief Bioinform 9, 299-306.

Kushmaro, A., Banin, E., Loya, Y., Stackebrandt, E. \& Rosenberg, E. (2001). Vibrio shiloi sp. nov., the causative agent of bleaching of the coral Oculina patagonica. Int J Syst Evol Microbiol 51, 1383-1388.

Lavilla-Pitogo, C. R., Baticados, M. C. L., Cruz-Lacierda, E. S. \& de la Pena, L. D. (1990). Occurance of luminous bacterial disease of Penaeus monodon larvae in Philippines. Aquaculture 91, 1-13.

Lin, Z., Yamasaki, S., Kurazono, H., Ohmura, M., Karasawa, T., Inoue, T., Sakamoto, T., Suganami, T., Takeoka, Y. \& other authors (1993). Cloning and sequencing of two new verotoxin 2 variant genes of Escherichia coli isolated from cases of human and bovine diarrhea. Microbiol Immunol 37, 451-459.

Lin, B., Wang, Z., Malanoski, A. P., O'Grady, E. A., Wimpee, C. F., Vuddakul, V., Alves, N., Jr, Thompson, F. L., Gomez-Gil, B. \& Vora, G. J. (2010). Comparative genomic analysis identify the Vibrio harveyi genome sequenced strains BAA-1116 and HY01 as Vibrio campbellii. Environ Microbiol Rep 2, 81-89.

Marques, A., Dinh, T., loakeimidis, C., Huys, G., Swings, J., Verstraete, W., Dhont, J., Sorgeloos, P. \& Bossier, P. (2005). Effects of bacteria on Artemia franciscana cultured in different gnotobiotic environments. Appl Environ Microbiol 71, 4307-4317.

Olsson, J. C., Westerdahl, A., Conway, P. L. \& Kjelleberg, S. (1992). Intestinal colonization potential of turbot (Scophthalmus maximus)and dab (Limanda limanda)-associated bacteria with inhibitory effects against Vibrio anguillarum. Appl Environ Microbiol 58, 551556.

Orozco-Medina, C., Maeda-Martinez, A. M. \& Lopez-Cortes, A. (2002). Effect of aerobic Gram-positive heterotrophic bacteria associated with Artemia franciscana cysts on the survival and development of its larvae. Aquaculture 213, 15-29.

Phuoc, L. H., Corteel, M., Nauwynck, H., Pensaert, J., Alday-Sanz, V., van der Broeck, W., Sorgeloos, P. \& Bossier, P. (2008). Increased susceptibility of white spot syndrome virus infected Litopenaeus vannamei to Vibrio campbellii. Environ Microbiol 10, 2718-2727.

Soto-Rodriguez, S. A., Simoes, N., Jones, D. A., Roque, A. \& GomezGil, B. (2003a). Assessment of fluorescent-labeled bacteria for evaluation of in vivo uptake of bacteria (Vibrio spp.) by crustacean larvae. J Microbiol Methods 52, 101-114. 
Soto-Rodriguez, S. A., Roque, A., Lizarraga-Partida, M. L., GuerraFlores, A. L. \& Gomez-Gil, B. (2003b). Virulence of luminous vibrios to Artemia franciscana nauplii. Dis Aquat Organ 53, 231-240.

Soto-Rodriguez, S. A., Simoes, N., Roque, A. \& Gomez-Gil, B. (2006). Pathogenicity and colonization of Litopenaeus vannamei larvae by luminescent vibrios. Aquaculture 258, 109-115.

Thompson, F. L., Hoste, B., Thompson, C. C., Huys, G. \& Swings, J. (2001). The coral bleaching Vibrio shiloi Kushmaro et al. 2001 is a later synonym of Vibrio mediterranei Pujalte and Garay 1986. Syst Appl Microbiol 24, 516-519.

Thompson, C. C., Thompson, F. L., Vandemenlebroecke, K., Hoste, B., Dawyndt, P. \& Swings, J. (2004a). Use of recA as an alternative phylogenetic marker in the family of Vibrionaceae. Int J Syst Evol Microbiol 54, 919-924.

Thompson, F. L., lida, T. \& Swings, J. (2004b). Bioviversity of Vibrio. Microbiol Mol Biol Rev 68, 403-431.
Thompson, F. L., Gevers, D., Thompson, C. C., Dawyndt, P., Naser, S., Hoste, B., Munn, C. B. \& Swings, J. (2005). Phylogeny and molecular identification of vibrios on the basis of multilocus sequence analysis. Appl Environ Microbiol 71, 5107-5115.

Thompson, F. L., Gomez-Gil, B., Vasconcelos, A. T. R. \& Sawabe, T. (2007). Multilocus sequence analysis reveals that Vibrio harveyi and V. campbellii are distinct species. Appl Environ Microbiol 73, 42794285.

Verschuere, L., Heang, G., Criel, G., Sorgeloos, P. \& Verstraete, W. (2000). Selected bacterial strains protect Artemia spp. from the pathogenic effects of Vibrio proteolyticus CW8T2. Appl Environ Microbiol 66, 1139-1146.

Wardlaw, A. C. (1985). Practical Statistics for Experimental Biologists. Chichester, UK: Wiley.

Edited by: S. D. Bentley 